\title{
AUDIT SISTEM INFORMASI SALES FORCE DENGAN MENGGUNAKAN FRAMEWORK COBIT 4.1
}

\author{
Mutia Dwi Rachmaningtyas ${ }^{1}$, Muhammad Dini ${ }^{2}$, Putri Aulia Ibrahim ${ }^{3}$ \\ 1,2,3 Jurusan Sistem Informasi Sekolah Tinggi Manajemen Informatika dan Komputer LIKMI Bandung \\ Jln. Ir. H. Juanda No.96 - Coblong Kota Bandung, Indonesia \\ ${ }^{1}$ mutiadwir13@gmail.com \\ ${ }^{2}$ muhammaddini347@gmail.com \\ ${ }^{3}$ Putriauliaibrahim@gmail.com
}

\begin{abstract}
Abstrak - Penggunaan Teknologi Informasi (TI) atau Sistem Informasi (SI) dalam hal ini System Informasi Sales Force di PT. Pos Indonesia (Persero) dengan tujuan untuk otomatisasi tenaga penjualan dengan sistem penjualan dan pemasaran produk yang terintegrasi melalui website, sehingga penjualan produk dapat langsung melaporkan dan memesan produk melalui website dengan menggunakan perangkat elektronik seperti computer. Maka dari itu, perlu dilakukan audit terkait dengan pengelolaan dan performa dari sistem informasi sales force tersebut. Untuk mengetahui tingkat kematangan dari pengelolaan dan performa dari system informasi tersebut, dilakukan analisis menggunakan framework Cobit 4.1 yang fokus pada domain DS1 Define and Manage Service Levels, DS3 Manage Performance and Capacity , DS10 Manage Problems , DS13 Manage Operations dan ME1 Monitor and Evaluate IT Performance. Hasil penelitian menunjukkan bahwa secara keseluruhan berdasarkan maturity level Cobit 4.1, sistem informasi sales force pada PT. Pos Indoesia (Persero) berada pada level 3 atau defined. Dapat disimpulkan bahwa, pengelolaan dan performa system informasi sales force tersebut sudah dilakukan secara baik oleh divisi TI di PT. Pos Indonesia (Persero).
\end{abstract}

Kata kunci : Domain, Framework Cobit 4.1, PT. Pos Indonesia (Persero), Sales Force, Website

\section{PENDAhuluan}

PT Pos Indonesia (Persero) adalah suatu perusahaan milik negara yang sudah beroperasi dalam jangka waktu yang lama dengan ruang lingkup kegiatannya tersebar luas meliputi seluruh wilayah di Indonesia. Perusahaan ini mempunyai tugas pokok membangun, mengusahakan, mengembangkan pelayanan di bidang lalu lintas pengiriman surat dan paket untuk mempertinggi penjualan jasa yang di operasikan oleh PT. Pos Indonesia (Persero) sendiri, dimana PT. Pos Indonesia (Persero) memiliki banyak kantor pos di seluruh nusantara mencapai 24.000 kantor pos dan pelayanan PT. Pos Indonesia (Persero) tidak hanya mencapai kabupaten saja, tetapi sudah mencapai pelosok-pelosok dalam negeri [1].

Seiring dengan kemajuan teknologi dan persaingan pasar yang semakin ketat, PT. Pos Indonesia (Persero) memiliki suatu system yaitu Sales Force. Sistem ini memberikan para sales untuk membantu representative untuk mengatur account dan track opportunities perusahaan, mengatur daftar kontak yang setiap personil miliki, mengatur jadwal kerja setiap personil, memberikan layanan training online yang dapat menjadi solusi untuk training jarak jauh, membangun dan mengawasi alur penjualan perusahaan dan membantu mengoptimalkan penyampaian informasi [2]. Jadi PT. Pos Indonesia memiliki sales force untuk men-tracking sales-sales perusahaan yang ada juga, agar terus terpantau hasil kerja karyawan, atau apa yang karyawan kerjakan itu baik buruknya semua dapat dilihat secara real.

Untuk tetap dapat bertahan serta bersaing dalam kancah bisnis kedepannya, keberadaan dan dukungan informasi yang akurat akan sangat memegang peranan penting dalam setiap keputusan pengelolaan system informasi Sales Force ini. Selain dari sisi teknologi, dukungan dari setiap karyawan yang berada dalam perusahaan juga berperan penting. Hal ini sangat dibutuhkan dalam hal pengetahuan tentang penggunaan dari sistem yang digunakan dalam perusahaan.

Sistem informasi dapat di definisikan sebagai suatu sistem di dalam suatu organisasi yang merupakan kombinasi dari orang-orang, fasilitas, teknologi, media, prosedur-prosedur dan pengendalian yang di tunjukan untuk mendapatkan jalur komunikasi penting, memproses tipe transaksi rutin tertentu, memberi sinyal kepada manajemen dan yang lainya terhadap kejadian-kejadian internal dan eksternal yang penting dan menyediakan suatu dasar informasi untuk pengambilan 
keputusan yang cerdik [3]. Dari definisi tersebut dapat ambil suatu kesimpulan bahwa, sistem informasi merupakan kumpulan dari komponen sistem yang saling berhubungan satu sama lain dan bekerjasama secara harmonis untuk mencapai suatu tujuan yaitu mengolah data untuk menghasilkan informasi yang berguna dalam pengambilan keputusan dan pengawasan dalam suatu organisasi serta membantu manajer dalam mengambil keputusan.

Untuk mengetahui tingkat pengelolaan dan performa dari system informasi sales force tersebut, dilakukan analisis terhadap tingkat kematangan menggunakan framework Cobit 4.1. COBIT (Control Objectives for Information and Related Technology) adalah sebuah framework dan supporting toolset yang membantu manager menjembatani jarak antara tujuan untuk keperluan pengendalian, permasalahan teknik (technical issue) dan resiko bisnis serta mengkomunikasikan level pengendalian kepada stakeholder [4]. Konsep kerangka kerja COBIT dapat dilihat dari tiga sudut pandang, yaitu kriteria informasi (information criteria), sumber daya TI (IT resources) dan proses TI (IT processes)[5].

Framework COBIT terdiri dari 3 tingkat objek kontrol, yaitu activities dan tasks, process, domains. Activities dan tasks merupakan kegiatan rutin yang memiliki konsep daur hidup, sedangkan task merupakan kegiatan yang dilakukan secara terpisah. Selanjutnya kumpulan activity dan task ini dikelompokan ke dalam proses TI yang memiliki permasalahan pengelolaan TI yang sama dan dikelompokan ke dalam 4 domains, yaitu Plan and Organise (PO), Acquire and Implement (AI), Deliver and Support (DS), Monitor and Evaluate (ME) [6].

Salah satu alat pengukur dari kinerja suatu sistem teknologi informasi adalah maturity level, yang berguna dalam pengontrolan setiap proses-proses teknologi informasi dengan metode penilaian (10). Untuk mengetahui tingkat kematangan tata kelola TI, maturity level dikategorikan menjadi 6 tingkat, diantaranya 0 - Non-existent, 1 - Initial/Ad Hoc, 2 Repeatable but Intuitive, 3 - Defined Process, 4 - Managed and measurable dan 5-Optimised [6].

Oleh sebab itu, Penulis bertujuan melakukan analisis mengenai tingkat pengelolaan dan performa pada sistem informasi Sales Force di PT. Pos Indonesia (Persero). Outputnya nanti diharapkan akan memberikan manfaat bagi PT. Pos Indonesia (Persero) dalam pengembangan system Informasi Sales Force maupun keputusan-keputusan yang diambil terkait dengan pengelolaan system informasi Sales Force itu sendiri dimasa yang akan datang.

\section{METOdologi PENELITIAN}

\section{A. Objek Penelitian}

Penelitian ini dilakukan di PT. Pos Indonesia (Persero) yang beralamat di Jalan Banda No.30, Kota Bandung, Jawa Barat.

\section{B. Metode Penelitian}

Sebagai roadmaps peneliti untuk menggambarkan prosesproses atau langkah-langkah yang dilakukan, maka Peneliti membuat sebuah diagram alir penelitian untuk memudahkan para pembaca dalam memahami serangkaian proses yang dilakukan sehingga mencapai hasil akhir dari penelitian ini.

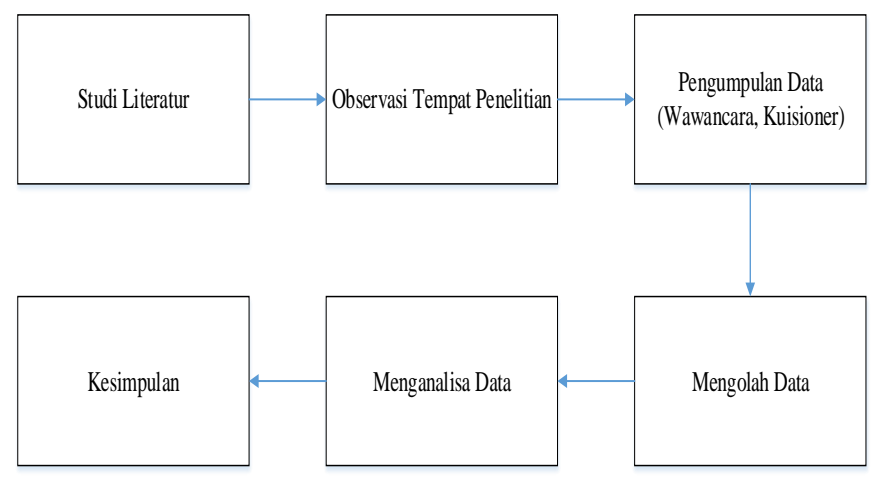

Gambar 1. Diagram Alir Penelitian

\section{Perhitungan Nilai Kematangan}

Maturity level diperoleh dengan menghitung setiap jawaban yang diberikan oleh responden dikalikan dengan bobot setiap jawaban yang telah ditentukan, kemudian dibagi dengan total pertanyaan. Pilihan jawaban yang diajukan menggunakan skala likert sebanyak 6 jawaban yang mewakili level maturity dari Cobit (level 0-5) [7]. Rumus perhitungan nilai maturity adalah sebagai berikut.

$$
\text { Nilai Maturity }=\frac{\sum(\text { Jawaban } \times \text { Bobot }}{\sum \text { Pertanyaan }}
$$

\section{Penentuan Domain Cobit 4.1}

Domain COBIT 4.1 yang digunakan oleh Peneliti untuk menganalisis system informasi Sales Force pada PT. Pos Indonesia (Persero), yaitu:

1) DS1 Define and Manage Service Levels: Komunikasi yang efektif antara TI dan bisnis manajemen pelanggan mengenai layanan yang dibutuhkan diaktifkan oleh definisi didokumentasikan dan kesepakatan layanan TI dan tingkat layanan. Proses ini juga mencakup pemantauan dan pelaporan yang tepat bagi pemegang saham atas pencapaian tingkat layanan. Proses ini memungkinkan keselarasan antara TI layanan dan kebutuhan bisnis yang terkait [8].

Berikut sub domain yang digunakan pada penelitian ini, antara lain :

- DS1.1 Service Level Management Framework

- DS1.2 Definition of Service

- DS1.3 Service Level Agreement

- DS1.4 Operating Level Agreements

- DS1.5 Monitoring and Reporting of Service Level Achievements

- DS1.6 Review of Service Level Agreements and Cotracts. 
2) DS3 Manage Performance and Capacity: Kebutuhan untuk mengelola kinerja dan kapasitas sumber daya TI membutuhkan proses untuk secara berkala meninjau kinerja saat ini dan kapasitas sumber daya TI. Proses ini meliputi peramalan kebutuhan masa depan berdasarkan beban kerja, penyimpanan dan persyaratan kontingensi. Proses ini memberikan jaminan bahwa informasi sumber daya yang mendukung kebutuhan bisnis yang terus tersedia [9].

Berikut sub domain yang digunakan pada penelitian ini, antara lain:

- DS3.1 Performance and Capacity Planning

- DS3.2 Current Performance and Capacity

- DS3.3 Future Performance and Capacity

- DS3.4 IT Resources Availability

- DS3.5 Monitoring and Reporting

3) DS10 Manage Problems: Masalah manajemen yang efektif memerlukan identifikasi dan klasifikasi masalah, analisis akar penyebab dan resolusi masalah. Proses manajemen masalah juga mencakup perumusan rekomendasi untuk perbaikan, pemeliharaan catatan masalah dan penelaahan tindakan korektif. Sebuah proses masalah manajemen yang efektif memaksimalkan ketersediaan sistem, meningkatkan tingkat layanan, mengurangi biaya, dan meningkatkan kenyamanan dan kepuasan pelanggan [4].

Berikut sub domain yang digunakan pada penelitian ini, antara lain:

- DS10.1 Identifikasi dan Klasifikasi Masalah

- DS10.2 Masalah Pelacakan dan Resolusi

- DS10.3 Masalah Penutupan

- DS10.4 Integrasi Manajemen Konfigurasi, Insiden, dan Masalah

4) DS13 Manage Operations: Pengolahan lengkap dan akurat data membutuhkan manajemen yang efektif dari prosedur pengolahan data dan pemeliharaan perangkat keras rajin. Proses ini termasuk menentukan kebijakan operasional dan prosedur manajemen yang efektif pengolahan dijadwalkan, melindungi output yang sensitif, pemantauan kinerja infrastruktur dan memastikan pemeliharaan preventif perangkat keras. Efektif manajemen operasi membantu menjaga integritas data dan mengurangi penundaan bisnis dan TI biaya operasi [9].

Berikut sub domain yang digunakan pada penelitian ini, antara lain:

- DS13.1 Operations Procedures and Instructions

- DS13.2 Job Schedulling

- DS13.3 IT Infrastructure Monitoring

- DS13.4 IT Sensitive Documents and Output Devices

- DS13.5 IT Preventive Maintenance for Hardware

5) ME1 Monitor and Evaluate IT Performance: TI manajemen kinerja membutuhkan proses pemantauan. Proses ini mencakup indikator kinerja mendefinisikan relevan, pelaporan yang sistematis dan tepat waktu dari kinerja, dan cepat bertindak atas penyimpangan. Pemantauan diperlukan untuk memastikan bahwa hal yang benar dilakukan dan sejalan dengan arah dan kebijakan ditetapkan [10].

Berikut sub domain yang digunakan pada penelitian ini, antara lain:

- ME1.1 Monitoring Approach

- ME1.2 Definition and Collection of Monitoring Data

- ME1.3 Monitoring Method

- ME1.4 Performance Assesment

- ME1.5 Board and Executive Reporting

- ME1.6 Remedial Actions

\section{HASIL DAN PEMBAHASAN}

Pada Bab ini, dilakukan analisis dan pembahasan mengenai system informasi sales force di PT. Pos Indonesia (Persero) dengan tujuan ingin mengukur, apakah system informasi sales force tersebut sudah sesuai pengelolaan dan performa yang ingin dicapai oleh organisasi. Dari hasil yang diperoleh Peneliti di obyek penelitian, digambarkan oleh beberapa domain yang sudah diklasifikasikan oleh Peneliti, bahwa domain tersebut sudah mampu untuk menggambarkan atau memberikan sebuah hasil yang akurat tentang tujuan yang ingin dicapai pada penelitian ini.

A. DS1 Define and Manage Services Levels

Fokus utama pada DS1 yaitu mencakup komunikasi yang efektif antara TI dengan bisnis management pelanggan mengenai layanan yang di butuhkan untuk dapat ditingkatkan. Proses ini menuntut keselarasan antara TI layanan dan kebutuhan bisnis yang terkait.

Dari hasil wawancara yang dilakukan oleh Peneliti pada obyek penelitian (PT. Pos Indonesia (Persero)) di bagian divisi teknologi bahwa penerapan teknologi informasi Sales Force memiliki prosedur yang sudah ditetapkan oleh Perusahaan dan penerapannya sudah diterapkan dan dikelola oleh hampir semua divisi yang terkait. Sehingga services (pelayanan) yang diberikan kepada Costumer (Pelanggan) telah sesuai dengan kebutuhan Customer tersebut.

1) DS1.1 Service Level Kerangka Kerja Manajemen: Menetapkan kerangka kerja yang memberikan tingkat pelayanan proses manajemen yang formal antara pelanggan dan operator. Kerangka itu harus menjaga keselarasan dengan kebutuhan bisnis yang berkesinambungan dengan prioritas dan memfasilitasi pemahaman bersama antara pelanggan dan operator.

Dari hasil wawancara dan analisis yang dilakukan bahwa semua penerapan yang dilakukan oleh operator system informasi Sales Force telah dijalankan sesuai dengan prosedur yang ditetapkan oleh management perusahaan. Prosedur standar system informasi sales force tersebut sudah dibuat oleh management perusahaan, sehingga setiap operator pada setiap divisi hanya tinggal menjalankan sesuai dengan prosedur yang ada. 
2) DS1.2 Definition of Service: Definisi dasar dari layanan TI pada kerangka karakteristik layanan dan kebutuhan bisnis di PT. Pos Indonesia Persero, dalam rangka memastikan bahwa perencanaan layanan terorganisir dan disimpan terpusat melalui penerapan pendekatan melalui portofolio layanan katalog.

Dari hasil analisis dan wawancara yang dilakukan pada pihak terkait bahwa penerapan layanan services sudah sesuai dengan kebutuhan pelanggan dan kemampuan TI yang dimiliki oleh setiap divisi.

3) DS1.3 Service Level Agreement: Services Level Agreements merupakan pendifinisian dan persetujuan terhadap SLAs untuk seluruh layanan TI yang kritis berdasarkan kebutuhan pelanggan dan kemampuan TI.

Dari hasil analisis dan wawancara bahwa didapatkan dari Operating Level Agreement dari Sales Force sudah optimal. Karena divisi TI sudah memberikan panduan untuk mengerjakan atau menghasilkan layanan secara baik dan benar. Dan jika ada kesalahan dari divisi lain, divisi TI akan segera membantu masalah tersebut. Perusahaan sudah memiliki tujuan, uraian tugas, ruang lingkup yang harus dikerjakan pada sistem Sales Force di perusahaan PT POS Indonesia.

4) DS1.4 Operating Level Agreements: OLAs merupakan model yang menjelaskan bagaimana layanan teknis mendukung SLAs secara optimal dan menspesifikasikan proses teknis yang berguna bagi penyedia jasa.

Dari hasil analisis dan wawancara yang dilakukan, didapatkan bahwa divisi TI telah melakukan monitoring dan reporting terhadap layanan, baik secara individual maupun kesuluruhan dengan cara divisi lain melakukan pengisian form yang telah disediakan oleh divisi TI dengan hasil baik atau buruk layanan yang diberikan divisi TI kepada divisi lain.

5) DS1.5 Monitoring and Reporting of Service Level Achievements: Untuk mengidentifikasi dan mengawasi kriteria kinerja tingkatan layanan terhadap layanan individual maupun keseluruhan layanan.

Dari hasil analisis dan wawancara yang dilakukan, didapatkan bahwa divisi lain telah melakukan atau menjalankan semua layanan berdasarkan prosedur yang diberikan oleh divisi TI.

6) DS1.6 Review of Service Level Agreements and Cotracts: Secara rutin melakukan tinjauan SLAs dan memberikan sokongan terhadap kontrak dengan penyedia layanan internal dan eksternal untuk memberikan kepastian bahwa penyediaan layanan tersebut efektif dan up to date serta bahwa pengubahan kebutuhan telah diperhatikan.

Dari analisis dan wawancara yang dilakukan, didapatkan bahwa perusahaan memiliki prosedur tata kerja yang harus dilakukan oleh sistem Sales Force antara lain, personel- personel harus melaksanakan dan bertanggung jawab pelaksaaan pekerjaan berpedoman pada tugas dan fungsi yang telah ditetapkan dalam keputusan direksi. Menetapkan prinsip koordinasi, integrasi, dan sinkronisasi dalam organisas Sales Force baik di lingkungan masing-masing maupun antar unit organisasi di lingkungan perusahaan serta dengan instansi lain di luar Perusahaan sesuai dengan tugas masing-masing.

\section{B. DS3 Manage Performance and Capacty}

Dari hasil analisis dan wawancara yang dilakukan, didapat hasil sebagai berikut:

1) Organiasasi melalui divisi TI telah menyediakan atau menentukan kapasitas kerja bagi masing-masing divisi dan menginformasikan prosedur tersebut kepada divisi lain, sehingga para personel di setiap divisi mengetahui dan menjalankan prosedur yang telah ditentukan.

2) Organisasi telah memiliki prosedur kapasitas kerja yang telah dibuat oleh divisi TI, sehingga para personel di divisi lain mengerti sampai mana mereka harus bekerja dan dimana ada hal-hal yang tidak usah mereka kerjakan atau mereka ketahui.

3) Organisasi memiliki prosedur untuk dilakukan pengecekan oleh personil terhadap gangguan-gangguan yang terjadi pada system sales force. Personel-personel memperbaiki setiap gangguan layanan, dari yang termudah hingga yang tersulit dan pengecekan tersebut dilakukan hanya satu bulan sekali terhadap system sales force tersebut, akan tetapi hasil yang dilakukan terhadap maintenance tersebut tidak ada.

4) Organisasi dalam hal ini PT. Pos Indonesia Persero memiliki Head of Sales yang berfungsi untuk merencanakan, mengkoordinasikan, mengendalikan, dan mengevaluasi atas aktifitas penggarapan pasar serta memeliharaan pelanggan dalam rangka pencapaian target pendapatan perusahaan sehingga sistem Sales Force yang ada pada perusahaan PT. Pos indonesia akan menangani dan memantai resiko layanan IT yang mungkin terjadi, tetapi Head Of Sales tersebut kurang dalam hal melakukan evaluasi terhadap personil yang dimiliki.

5) Sebagaimana yang dijabarkan pada point 5 bahwa PT. Pos Indonesia memiliki Head Of Sales yang harus melaksanakan fungsi dan tugas pokok serta tanggung jawab untuk mengawasi atau memantau, mengevaluasi atas merealisasikan perencanaan sumber daya TI. Tetapi, Head of Sales tersebut kurang memberikan pengawasan ke semua personil yang ada pada perusahaan.

\section{DS10 Manage Problems}

Dari hasil analisis dan wawancara yang dilakukan, didapat hasil sebagai berikut:

1) Dari hasil identifikasi dan klasifikasi masalah yang dilakukan, terdapat berbagai masalah yang ditemukan antara lain aplikasi yang digunakan belum semua karyawan atau divisi dapat langsung menggunakannya, 
dibutuhkan pembelajaran beberapa minggu agar karyawan atau divisi lain dapat menggunakan aplikasi dengan baik dan benar dan perusahaan sudah mengatasi masalah-masalah tersebut.

2) PT. Pos Indonesia Persero melaui divisi TI melakukan penyelesaian masalah dengan cara melakukan rapat untuk menentukan dan pengambilan keputusan untuk sebuah masalah dan dapat dilihat dari bukti yang didapatkan.

3) Untuk menyelesaikan permasalahan yang terjadi, Perusahaan melalui divisi Ti melakukan rapat dan dari rapat tersebut akan mengundang fungsi yang terkait atau pihak yang bersangkutan untuk menjelaskan tentang prosedur penyelesaian masalah yang telah dilakukan.

4) Perusahaan dalam menghadapi masalah integrasi manajemen konfigurasi, insiden, dan masalah dengan cara melakukan rapat dan mengundang semua fungsi atau pihak yang terkait dengan masalah yang mereka hadapi, di dalam rapat tersebut akan membahas dan melakukan pengambilan keputusan untuk penyelesaian masalah tersebut dan akan menghasilkan notulen

\section{DS13 Manage Operation}

Dari hasil analisis dan wawancara yang dilakukan, didapat hasil sebagai berikut:

1) Untuk mendukung operasi system sales force, PT. Pos Indonesia memiliki prosedur yang dikelola dan disimpan secara baik oleh divisi TI.

2) Untuk mengatur penjadwalan pekerjaan, proses dan tugas yang dilakukan oleh setiap divisi agar memenuhi persyaratan bisnis, PT. Pos Indonesia melalui divisi TInya melaksanakan tugas tersebut sesuai dengan prosedur yang telah ditentukan.

3) PT. Pos Indonesia melalui divisi TI melakukan monitoring terhadap operasi yang dilakukan oleh divisi lain dengan cara memeriksa form yang diisi oleh setiap divisi yang bersangkutan.

4) PT. Pos Indonesia melalui divisi TI yang bertugas untuk menyimpan data atau dokumen-dokumen yang bersifat rahasia masih kurang dalam hal penanganannya.

5) Untuk mencegah kegagalan operasi system sales force dari sisi hardware, divisi TI melakukan maintenance yang dilakukan 3 bulan satu kali, tetapi maintenance tersebut tidak ada di dalam prosedur kegiatan.

\section{E. ME1 Monitoring and Evaluate IT Performance}

Dari hasil analisis dan wawancara yang dilakukan, didapat hasil sebagai berikut:

1) Perusahaan telah melakukan manajemen dan monitoring yang dijalankan oleh divisi TI terhadap system informasi sales force terhadap performance dan layanan yang diberikan oleh divisi-divisi lain.

2) Perusahaan telah melakukan identifikasi untuk mengukur target atau pencapaian yang akan dituju oleh sales force.

3) Para Manajer dan Supervisor di dalam perusahaan telah melakukan pengawasan terhadap tim-tim Sales force dengan mekanisme pengawasan menggunakan pengisian form yang telah disediakan.

4) Perusahaan dalam hal ini PT. Pos Indonesia (Persero) dalam melakukan identifikasi masalah dan perbaikan masalah tersebut dengan melakukan rapat untuk menentukan perbaikan masalah dan hasilnya adalah sebuah laporan.

5) Perusahaan telah melakukan manajemen pelaporan kinerja serta target yang ingin dicapai oleh divisi-divisi yang bersangkutan.

6) Perusahaan telah melakukan identifikasi dan tindakan perbaikan berdasarkan kinerja dan pelaporan dengan benar. Dan masalah atas perbaikan harus diidentifikasi dan dikelompokan tingkat kekritisan, sensitivitas, dan risiko oleh pemilik data. Pengklasifikasian prosedur tersebut dibagi menjadi 4 tingkat, yaitu biasa,sedang,tinggi,dan sangat tinggi.

\section{F. Hasil Perhitungan Nilai Maturity}

Berdasarkan data yang diperoleh dari kuisioner yang telah diisi oleh responden pada PT. Pos Indonesia (Persero), dilakukan perhitungan menggunakan Persamaan (1) pada masing-masing domain yang diteliti. Hasil dari perhitungan nilai maturity setiap domain ditunjukan oleh table-tabel berikut ini.

TABEL I

Domain DS1 Defined and Manage Service Levels

\begin{tabular}{|c|c|c|}
\hline Domain & Control Objectives & Level Maturity \\
\hline \multirow{6}{*}{$\begin{array}{c}\text { DS1 Defined and } \\
\text { Manage Service Levels }\end{array}$} & $\begin{array}{l}\text { DS1.1 Services Level } \\
\text { Management } \\
\text { Framework }\end{array}$ & Level 3 (Defined) \\
\hline & $\begin{array}{l}\text { DS1.2 Definition Of } \\
\text { Services }\end{array}$ & Level 3 (Defined) \\
\hline & $\begin{array}{l}\text { DS1.3 Service Level } \\
\text { Agreements }\end{array}$ & Level 3 (Defined) \\
\hline & $\begin{array}{l}\text { DS1.4 Operating Level } \\
\text { Agreements }\end{array}$ & Level 3 (Defined) \\
\hline & $\begin{array}{l}\text { DS1.5 Monitoring and } \\
\text { Reporting of Service } \\
\text { Level Achievements }\end{array}$ & Level 3 (Defined) \\
\hline & $\begin{array}{lr}\text { DS1.6 Review } & \text { of } \\
\text { Service } & \text { Level } \\
\text { Agreements } & \text { and } \\
\text { Contracts } & \\
\end{array}$ & Level 3 (Defined) \\
\hline Kesimpulan & \multicolumn{2}{|c|}{$\begin{array}{l}\text { Sehingga hasil didapatkan DS1 Define and } \\
\text { Manage Service Levels tergolong dalam } \\
\text { maturity model level } 3 \text { yaitu defined }\end{array}$} \\
\hline
\end{tabular}

TABEL II

Domain DS3 Manage Performance and Capacity

\begin{tabular}{|c|c|c|}
\hline Domain & Control Objectives & Level Maturity \\
\hline \multirow{3}{*}{$\begin{array}{c}\text { DS3 Manage } \\
\text { Performance and } \\
\text { Capacity }\end{array}$} & $\begin{array}{lr}\text { DS3.1 Performance } \\
\text { and Capacity Planning }\end{array}$ & Level 3 (Defined) \\
\hline & $\begin{array}{lr}\text { DS3.2 } & \text { Current } \\
\text { Performance } & \text { and } \\
\text { Capacity } & \\
\end{array}$ & Level 3 (Devined) \\
\hline & $\begin{array}{lr}\text { DS3.3 } & \text { Future } \\
\text { Performance } & \text { and } \\
\text { Capacity } & \\
\end{array}$ & Level 3 (Defined) \\
\hline
\end{tabular}




\begin{tabular}{|l|l|l|}
\hline \multirow{2}{*}{} & $\begin{array}{l}\text { DS3.4 IT Resources } \\
\text { Availability }\end{array}$ & Level 3 (Devined) \\
\cline { 2 - 3 } & $\begin{array}{l}\text { DS3.5 Monitoring and } \\
\text { Reporting }\end{array}$ & Level 3 (Defined) \\
\hline Kesimpulan & $\begin{array}{l}\text { Sehingga hasil didapatkan DS3 Manage } \\
\text { Performance and Capacity tergolong dalam } \\
\text { maturity model level 3 yaitu defined }\end{array}$ \\
\hline
\end{tabular}

TABEL III

Domain DS10 Manage Problems

\begin{tabular}{|c|l|l|}
\hline Domain & Control Objectives & Level Maturity \\
\hline \multirow{5}{*}{$\begin{array}{c}\text { DS10 Manage } \\
\text { Problems }\end{array}$} & $\begin{array}{l}\text { DS10.1 Identifikasi dan } \\
\text { Klarifikasi Masalah }\end{array}$ & Level 3 (Defined) \\
\cline { 2 - 3 } & $\begin{array}{l}\text { DS10.2 Masalah } \\
\text { Pelacakan dan Resolusi }\end{array}$ & Level 3 (Defined) \\
\cline { 2 - 3 } & $\begin{array}{l}\text { DS10.3 Masalah } \\
\text { Penutupan }\end{array}$ & Level 3 (Defined) \\
\cline { 2 - 3 } & $\begin{array}{l}\text { DS10.4 Integrasi } \\
\text { Manajemen Insiden } \\
\text { Konfigurasi, Level 3 (Defined) } \\
\text { Masalah }\end{array}$ \\
\hline Kesimpulan & $\begin{array}{l}\text { Sehingga hasil didapatkan DS10 Manage } \\
\text { Problems tergolong dalam maturity model level } \\
\text { 3 yaitu defined }\end{array}$ \\
\hline
\end{tabular}

TABEL IV

Domain DS13 Manage Operations

\begin{tabular}{|c|c|c|}
\hline Domain & Control Objectives & Level Maturity \\
\hline \multirow{5}{*}{$\begin{array}{c}\text { DS13 Manage } \\
\text { Operations }\end{array}$} & $\begin{array}{lr}\text { DS13.1 } & \text { Operations } \\
\text { Procedures } & \text { and } \\
\text { Instructions } & \\
\end{array}$ & Level 3 (Defined) \\
\hline & DS13.2 Job Scheduling & Level 3 (Defined) \\
\hline & $\begin{array}{ll}\text { DS13.3 IT } \\
\text { Infrastructure } \\
\text { Monitoring }\end{array}$ & Level 3 (Defined) \\
\hline & $\begin{array}{l}\text { DS13.4 Sensitive } \\
\text { Documents and Output } \\
\text { Devices }\end{array}$ & Level 3 (Defined) \\
\hline & $\begin{array}{lr}\text { DS13.5 Preventive } \\
\text { Maintenance } \\
\text { Hardware }\end{array}$ & Level 3 (Defined) \\
\hline Kesimpulan & $\begin{array}{l}\text { Sehingga hasil didap } \\
\text { Operations tergolong da } \\
3 \text { yaitu defined }\end{array}$ & $\begin{array}{l}\text { atkan DS13 Manage } \\
\text { am maturity model level }\end{array}$ \\
\hline
\end{tabular}

TABEL V

Domain ME1 Monitor and Evaluate IT Performance

\begin{tabular}{|c|l|l|}
\hline Domain & Control Objectives & Level Maturity \\
\hline \multirow{5}{*}{$\begin{array}{l}\text { ME1.1 Monitoring } \\
\text { Approach }\end{array}$} & Level 3 (Defined) \\
\cline { 2 - 3 } $\begin{array}{c}\text { Evaluate IT } \\
\text { Performance } \\
\text { Collection Definition and of } \\
\text { Monitoring Data }\end{array}$ & Level 3 (Defined) \\
\cline { 2 - 3 } & $\begin{array}{l}\text { ME1.3 Monitoring } \\
\text { Method Level 3 (Defined) }\end{array}$ \\
\cline { 2 - 3 } & $\begin{array}{l}\text { ME1.4 Performance } \\
\text { Assesment }\end{array}$ & Level 3 (Defined) \\
\cline { 2 - 3 } & $\begin{array}{l}\text { ME1.5 Board and } \\
\text { Executive Reporting }\end{array}$ & Level 3 (Defined) \\
\cline { 2 - 3 } & $\begin{array}{l}\text { ME1.6 Remedial } \\
\text { Actions Level 3 (Defined) }\end{array}$ \\
\hline \multirow{2}{*}{ Kesimpulan } & $\begin{array}{l}\text { Sehingga hasil didapatkan ME1 Monitor and } \\
\text { Evaluate IT Performance tergolong dalam maturity } \\
\text { model level 3 yaitu defined. }\end{array}$ \\
\hline
\end{tabular}


PengembanganTeknologi Inf. dan Ilmu Komput., vol. 2, no. 12, pp. 6688-6696, 2018.

[3] A. M. Andreas Andoyo, Siti Mukodimah, "Implementasi Mobile Commerce Untuk Meningkatkan Pendapatan Anggota Koperasi Gentiaras Pringsewu," J. Teknol. Komput. dan Sist. Inf., vol. 03, no. 01, pp. 37-41, 2020.

[4] J. F. Andry, "Audit Sistem Informasi Sumber Daya Manusia Pada Training Center Di Jakarta Menggunakan Framwork Cobit 4.1," J. Ilm. FIFO, vol. 8, no. 1, pp. 1-7, 2016.

[5] N. Azizah, "Audit Sistem Informasi Menggunakan Framework Cobit 4.1 Pada E-Learning Unisnu Jepara," Simetris J. Tek. Mesin, Elektro dan Ilmu Komput., vol. 8, no. 1, pp. 377-382, 2017.

[6] F. Adityo, Suprapto, and A. D. Herlambang, "Implementasi Kerangka Kerja Cobit 4 . 1 Domain Acquire and Implement ( AI ) Terhadap Implementasi Kerangka Kerja Cobit 4.1 Domain Acquire and Implement (AI) Terhadap Tata Kelola Teknologi Informasi (Studi Kasus: Dinas Komunikasi dan Informatika Kota Bukit," J. Pengemb. Teknol. Inf. dan Ilmu Komput., vol. 3, no. 2, pp. 2010-2019, 2019.

[7] E. Ekowansyah, Y. H. Chrisnanto, Puspita, and N. Sabrina, "Audit Sistem Informasi Akademik Menggunakan COBIT 5 di Universitas Jenderal Achmad Yani," Pros. Semin. Nas. Komput. dan Inform., pp. 201-206, 2017.

[8] Jelvino and J. F. Andry, "Audit Sistem Informasi Absensi pada PT . Bank Central Asia Tbk menggunakan COBIT 4 . 1," J. Tek. Inform dan Sist. Inf., vol. 3, no. 2, pp. 259-268, 2017.

[9] Fenny and J. F. Andry, "Audit Sistem Informasi Menggunakan Framework Cobit 4.1 Pada Pt. Aneka Solusi Teknologi," Semin. Nas. Sains dan Teknol., pp. 1-11, 2017.

[10] J. F. Andry, Y. M. Geasela, and J. Junior, "Penggunaan COBIT 4 . 1 Dengan Domain ME Pada Sistem Informasi Absensi Penggunaan COBIT 4 . 1 Dengan Domain ME Pada Sistem Informasi Absensi ( Studi Kasus : Universitas XYZ ),” J. Ilm. Ilmu Komput., vol. 13, no. 2, pp. $97-101,2018$. 